\title{
Baranyai Decsi Csimor János emlékezete
}

A magyar müvelődés egyetemességének jellegzetes bizonysága, hogy a török hódoltság alá került Felső-Baranya Decs nevü falujában negyedfél évtizeddel a mohácsi vész után született Baranyai Decsi Csimor János Kolozsvárt, Wittenbergben, Strasbourgban szerzett tudását a Marosvásárhelyt éppen szárnyait bontogató - majd száz év múltával kollégiummá izmosodó Schola falai között kamatoztatta és emelte klasszikus rangra.

Halála 400. évfordulóján (2001. május 15-én) az Erdélyi Múzeum-Egyesület a marosvásárhelyi vártemplomi egyházközséggel és a Teleki Alapítvánnyal együttmüködve, ünnepélyesen emlékezett meg a Marosvásárhelyt 1601. május 15-én meghalt és a templom melletti cinteremben eltemetett, rektorságot viselt nevelöről, a filozófiában, a filológiában, a jog- és történettudományban maradandót alkotott tudósról és versei bizonysága szerint a szépliteratúrában igencsak járatos poétáról.

A vártemplom északi oldalában egykor otthonra lelt iskola falára emléktáblát helyeztünk, és a gótikus teremben tudományos szimpóziumon marosvásárhelyi, kolozsvári, veszprémi és budapesti kutatók saját búvárlataikra alapozott előadásaikkal méltatták Baranyai Decsi nevelői, tudományos és költői érdemeit.

A szép számmal összesereglett megemlékezőket az EME elnöke, a marosvásárhelyi vártemplom és Decs református lelkipásztora köszöntötte, és együtt leplezték le a vistai mészkőből faragott emléktáblát. A kőtáblára ezt írtuk:

\section{E FALAK TÖVÉBEN \\ TEMETTÉK EL 1601-BEN \\ BARANYAI DECSI CSIMOR JÁNOS \\ HUMANISTA TUDÓS TANÁRT}

Baranyai Decsi müveit a Teleki Tékában alkalmi kiállításon tekinthették meg az ünnepi megemlékezés résztvevöi.

A marosvásárhelyi rendezvény akár szimbolikusnak is minősíthető szép mozzanata volt, hogy azon részt vett a baranyai szülőföld (Decs) és az örök nyugvóhely (Marosvásárhely) hivatalos polgári küldöttsége.

A rendezvényt támogatta a Magyar Tudományos Akadémia Magyar Tudományosság Külföldön Elnöki Bizottsága.

Az alább következőkben közzétesszük az ünnepi megemlékezésen elhangzott előadások bővített, szerkesztett változatát. Már szerkesztettük ünnepi megemlékezésünknek ezt a nyomtatott változatát, amikor hír érkezett Marosvásárhelyről Tóth István hirtelen haláláról, akinek így utolsó nyilvános szereplése éppen az általa nagyra értékelt Baranyai Decsi költői munkásságának körünkben elhangzott méltatása volt.

Benkö Samu 